\title{
Debt Policy: Affecting Factors and Their Impact on Company Values
}

\author{
Rofika $^{1 *}$ Vera Oktari ${ }^{2}$ \\ 1. Lecturer of Accounting the Faculty of Economic and Bisniss, University of Riau \\ Campus Binawidya KM.12,5 Simpangbaru, Tampan, Pekanbaru, Riau, 28296 \\ 2. Lecturer of Accounting the Faculty of Economic and Bisniss, University of Riau \\ Campus Binawidya KM.12,5 Simpangbaru, Tampan, Pekanbaru, Riau, 28296
}

\begin{abstract}
One of the main sources of funding for operational activities and company expansion is derived from debt. The company's debt policy is a policy made by the management as the manager of the company. The debt policy will have an impact on the company value as reflected in the market price of the company's shares. This study aims to prove the factors that influence the company's debt policy and the impact of the debt policy on the company value. The factors that influence debt policy as an independent variable of this study are: managerial ownership, institutional ownership, company growth, free cash flow and company size. The company's debt policy is proxied by the Debt to Equity (DER) ratio and the company value is proxied by the Price to Book Value (PBV) ratio. The research sample is a manufacturing company selected based on criteria, so as to obtain as many as 91 companies registered in 2014-2016. Using multiple regression analysis on alpha $=5 \%$, the results show that managerial ownership and Free cash flow affect the company's debt policy, while other variables have no effect on it. Debt policy did not affect the value of the company.
\end{abstract}

Keywords: Debt policy, company value, managerial ownership, free cash flow, company size

DOI: $10.7176 /$ RJFA/10-14-14

Publication date:July $31^{\text {st }} 2019$

\section{Introduction}

The purpose of establishing a company according to Harjito (2005) is: (1) to achieve maximum goals or maximum profits, (2) to prosper the owner of the company or shareholders, and (3) to maximize the company value. To achieve these objectives the main factor needed by the company is the availability of funds to finance the company's operations. The source of the company's funding comes from internal and external funds. Internal company funds, namely the source of funds obtained from the company in the form of current year profits, retained earnings and share capital. External funds are funds originated from outside the company in the form of debt.

External funding will be related to the debt policy made by management. Debt policy is one of the funding decisions made to increase company funds that will be used to meet the company's operational needs. It will encourage company management to be more careful in optimizing the use of these funds. With the existence of debt, the company has the obligation to make payments on the principal and interest on the debt periodically. Failure to repay corporate debt will affect management performance. Thus, debt can reduce agency conflict between management and shareholders.

The debt made at the company's management policy will have an impact on the company value within the eyes of investors or prospective investors. As a result, failure to pay debts will cause the company to be in a state of financial distress which ultimately can lead to bankruptcy. An example is the one that is experienced by PT Dwi Aneka Jaya Kemasindo Tbk (DAJK) which was declared bankrupt by the Central Jakarta Commercial Court on November 22, 2017 (emitennews.com, 2018). The bankruptcy claim came from PT Bank Mandiri Tbk (BMRI), which assessed the debtor's bankruptcy as the only way to get a debt repayment.

In addition, failure to pay debts will also have an impact on the company value in the form of a decrease in the company's stock price,as experienced by PT Tiga Pilar Sejahtera FoofTbk (AISA). AISA's stock price has gradually dropped since it was caught in a legal case that caused analysts not to recommend this stock for the long term, especially a lot of homework for AISA to overcome debt and make its performance better (investment.kontan.co.id, 2018).

This study focused on the company's debt policy with the population of manufacturing sector companies listed on 
the Indonesia Stock Exchange from 2015 to 2017. This was done with a number of considerations, i.e.: (1) due to the limited time to collect, process and analyze data and interpret the results of data processing from making proposals to completion of the final report. (2) Due to differences in characteristics between several sectors with other sectors, it is difficult to compare results in a comprehensive manner. (3). The manufacturing sector is the largest sector with the largest number of companies with characteristics that are in accordance with the data needed in this study so that they are considered to be representative.

Data on the average debt of manufacturing companies listed on the Indonesia Stock Exchange from 2013 to 2016 obtained from the company's financial statements can be seen in the following table:

Tabel 1 Average Debt of Manufacturing Companies from 2013 to 2016

\begin{tabular}{|c|c|c|}
\hline No & Year & Amount of Debt \\
\hline 1. & 2013 & Rp3.037.292.000,- \\
\hline 2. & 2014 & Rp4.146.305.000,- \\
\hline 3. & 2015 & Rp4.083.355.000,- \\
\hline 4. & 2016 & Rp4.322.696.000,- \\
\hline
\end{tabular}

Source: Processed Data

From the table above, it can be seen that the corporate debt of the manufacturing sector listed on the Indonesia Stock Exchange may be said to have increased every year. This shows that the company's external funding needs also increased. An external funding decision originating from debt is a policy taken by management. Thus, debt policy plays an important role as a source of operational funding for the company. In making decisions regarding debt policy, of course, company management considers some various factors.

The various factors that influence the company's debt policy have been investigated by several previous researchers In this study the factors that influence company's debt policy consist of managerial ownership, institutional ownership, company growth, free cash flow and company size.

Managerial ownership is the number of shares circulating in the company owned by managers who actively participate in corporate decision making (directors and board of commissioners) (Wahidahwati, 2002). According to agency theory, large shareholders are more motivated and have greater power to guarantee the maximization of shareholder value. Managerial ownership of company shares can align management interests with other shareholders so as to reduce the potential for agency conflict. Greater managerial ownership causes management to be more careful in using debt because they also bear the consequences of their actions so that management tends to use low debt.

The results of the research by Indana (2010), Natasia and Wahidahwati (2015) found that managerial ownership had a negatively significant effect on debt policy. Milanto (2012) found managerial ownership had a positively significant effect on debt policy. While Nasrizal (2010), Oktaviani (2012), Larasati (2011), Indahningrum and Handayani (2009) found managerial ownership had no effect on debt policy.

Institutional ownership is the proportion of shares held by an institution or business entity or organization. Institutional ownership has capabilities that are better than individual ownership. Large institutional ownership can affect the company's debt policy. Greater institutional ownership will be more able to oversee management actions on debt policy. Higher managerial ownership will affect the decrease in debt usage.

The results of the research conducted by Indahningrum and Handayani (2009), Nasrizal (2010) and Larasati (2011) found that institutional ownership has a positively significant effect on debt policy. The results of research conducted by Wahidahwati (2002), Yeniatie and Destriana (2010), Milanto (2012), found that institutional ownership had a negatively significanteffect on debt policy. Whereas Narita (2012), Surya and Rahayuningsih (2012) and Natasia and Wahidahwati found institutional ownership had no effect on debt policy.

The company's growth is a picture of the business development carried out in the current period compared to the previous period (Hardiningsih and Oktaviani (2012). Based on the pecking order theory, companies that have high growth will reduce their debt policy because they illustrate that the company has sufficient source of funds to finance the company. The company's growth shows the performance of the company achieved in investing and business activities so that the greater the growth rate,the higher their ability should be to provide the company with sufficient funds so that it is not too dependent on external funding.

The results of the research conducted by Stefen and Lina (2011), Hardiningsih and Oktaviani (2012) found that the company's growth had a negatively significant effect on the company's debt policy. Yenietie and Destriana (2010) found that company growth had a positively significant effect on corporate debt policy. While the results of the research conducted by Indahningrum and Handayani (2009) and Natasia and Wahidahwati (2015) found 
that the company's growth did not affect the company's debt policy.

Free Cash Flow is the amount of cash available to investors after the company meets all of the company's operating needs and investment needs. Large free cash flow can affect management's opportunistic behavior to use it for management's personal interests. Whereas other shareholders want free cash flow to be distributed in the form of dividends. To reduce agency conflicts that occur management can use debt as a source of funding. The greater the free cash flow, the greater corporate debt policy will result.

The results of the research conducted by Indahningrum and Handayani (2009), Natasia and Wahidahwati (2015) found that free cash flow has a positively significant effect on debt policy.

The size of the company directly reflects the high and low operating activities of a company. The bigger the company, the greater the activity. High activity requires large funding. Large companies have great access to the capital market so that it will make it easier to create debt. It can be concluded that the larger the company, the greater the company's debt policy. The results of the research conducted by Milanto (2012) found that the size of the company had a positively significant effect ondebt policy. While Soesetio (2008) and Sujarweni et al (2014) found that company size did not affect debt policy.

The fluctuations in the company value areaffected by the use of debt. On one hand the high use of debt can increase the value of the company because the use of debt can save taxes. However, it can also reduce the value of the company because of the possibility of bankruptcy costs and agency costs. Debt can also be a source of funds for companies to pay dividends to shareholders. By paying dividends, it is expected to attract investors to buy the company's shares. Thus, the size of the debt used will affect the company value.

Some previous studies have succeeded in proving the influence of debt policy on company value. The results of the study conducted by Sukrini (2012), Afzal and Rohman (2012), Hermuningsih (2013), Irvaniawati and Urtiyati (2014), proved that the company's debt policy influences the company value. On the other hand, the results of research conducted by Mardiyati (2012), Martikarini (2012), Mayogi (2012) and Sari and Wijayanto (2015) found that debt policy does not affect the company value.

Based on the description above, the research questions can be formulated as follows:

1. Is managerial ownership, institutional ownership, company growth, free cash flow, and company size influencing debt policy?

2. Does the debt policy affect the company value?

The purpose of this study is:

1. Proving and analyzing the influence of managerial ownership, institutional ownership, company growth, free cash flow, and company size on debt policy.

2. Proving and analyzing the influence of debt policy on company value

\section{Theoretical Framework and Hypotheses Development}

\subsection{Debt Policy}

Debt policy is a company policy to finance its operations from outside the company (external). The main source of external funds is derived from creditors, namely in the form of loans or debt. Some companies assume that the use of debt is considered safer than issuing new shares. Thus, the higher the debt policy is carried out, the higher the company value is (Brigham and Ehrhardt, 2005). Debt policy is a policy that determines how much needs of a company need to be financed by debt (Weston and Copeland, 1992 in Diana, 2011).

Some theories relating to company's debt policies include:

1. Capital Structure Theory by Miller and Modigliani (1963). In this theory they argue that assuming no taxes, no bankruptcy costs, the absence of asymmetric information between management and shareholders, and the market involved in an efficient condition, then the value that can be achieved by the company is not related to how the company does their funding strategy.After eliminating the assumption about the absence of taxes, debt can save paid taxes (because debt raises interest payments that reduce the amount of income taxed) so that the company value increases.

2. Trade off theory (Brigham and Houton, 2001). The trade off theory explains that interest is a deductible expense which results in cheaper debt than ordinary shares or preferred shares. As a result, the government pays part of the cost of capital originated from debt, in other words, debt provides tax protection benefits. The greater the proportion of debt is, the greater the tax protection obtained. 


\subsection{The company value}

Company value is a description of the condition of a company, where there is a special assessment by prospective investors on the good and bad financial performance done by the company. Company value is a certain condition that has been achieved by a company as a picture of public trust in the company after going through an activity process for several years, since the company was first established until now. The community judges by being willing to buy shares of a company at a certain price according to their perceptions and beliefs (Sudiyatno, 2010).

Company value is an investor's perception of the level of success of the company that is closely related to its stock price (Sujoko and Soebiantoro, 2007). High stock prices will make the companyvalue also higher. Thus, it can increase market confidence in the company performance, not only at this time but also towards the company's prospects in the future.

According to Husnan and Pudjiastuti (2012) the value of the company is the price that the prospective buyer is willing to pay if the company is sold. Whereas according to Keown (2011) company value is the market value of outstanding debt securities and company equity.

In order to become a company that becomes the target of investors, company owners or shareholders will try to increase the value of their company. This is also in accordance with the company's main goal; to increase the company value. Increasing the company value is an achievement, because with the increase in the company value, the prosperity ofthe owners will also increase. The value company is reflected in the price of the company's shares on the stock exchange. The higher the stock price means the higher the value of the company is, which means increasing shareholder prosperity (Brigham, 2001).

\subsection{Managerial Ownership}

Managerial ownership is the proportion of shareholders from management who actively participate in company decision making (directors and commissioners) (Diyah and Erman, 2009). The presence of managerial ownership in a company will lead to interesting suspicion that the company value increases as a result of increasing managerial ownership. Ownership by large management will effectively monitor company activities.

The theory commonly used in relation to managerial ownership is Agency Theory. According to agency theory, agency relations occur when one person or more (principal) employs another person (agent) to provide a service and then delegates decision-making authority to the agent (Jensen and Meckling, 1976) The interests of owners often conflict with those of management. This will lead to a conflict called agency conflict. Agency conflict occurs because managers tend to prioritize their personal interests rather than the goal of maximizing the prosperity of shareholders or company owners.

Managerial ownership in a company is seen to be able to harmonize the potential differences in interests between management and other shareholders. Agency problems will be eliminated assuming the company manager is also the owner of the company.

\subsection{Institutional Ownership}

Institutional ownership is the number of shares held by institutional investors or business entities or companies within a company. Institutional investors are investors in the form of institutions or business entities such as companies. According to agency theory, the existence of institutional investors can reduce agency conflicts due to differences in the interests of managers and other shareholders.

\subsection{Company Growth}

Company growth is a change in total assets in one period or one year in the form of an increase or decrease in assets. Companies with high growth rates tend to use external funds. The most preferred external party funding is debt.

According to the pecking order theory, companies prioritize funding from internal sources. Based on this theory, companies with high growth rates should reduce their debt policy because companies with high growth rates describe the company as having a large source of funds to finance its activities. Company growth is a description of the company's performance achieved in investing and business activities, so that greater the growth rate, the more the company should be able to meet the needs of the company therefore there is no need to use funds from outside parties. 
The higher the growth rate of the company is, the smaller the debt is taken by the company because the company will prefer internal funding sources compared to riskier debt policy making.

\subsection{Free Cash Flow}

Free Cash Flowis excess cash needed to fund all projects that have a positive net present value after dividing dividends (Jensen, 1986 in Indahningrum and Handayani, 2009). According to Bringham and Houston (2001) free cash flow describes how much cash is available to be distributed to investors after the company meets the investment needs and investment needs of the company. Free cash is cash available above investment needs that are profitable and are the rights of shareholders. The greater the free cash flow available in the company, the healthier the company is because it has cash available for growth, debt payments and dividends.

The greater the available free cash flow, the greater the agency conflict will caused. The management prefers free cash available for personal interests while other shareholders prefer it to be distributed in the form of dividends. To minimize this natural conflict and to be able to control the use of excessive free cash flow by managers, the manager can choose debt as a source of corporate funding.

\subsection{Company Size}

The size of the company reflects the high and low operating activities of a company. In general, the larger the company the greater the activity (Hastalona, 2013). According to Setiyadi (2007) the size of the company commonly used to determine the level of the company is:

1. Labor, is the number of permanent and honorary employees who are registered or work in the company at a certain time.

2. The level of sales, is the sales volume of a company in a certain period.

3. Total Debt, is the amount of the company's debt for a certain period.

4. Total assets, are all assets owned by the company at certain times.

\subsection{Effect of Managerial Ownership on Debt Policy}

Managerial ownership shows that there is a dual role of managers in a company that is as a company manager as well as a company shareholder. According to the agency theory (Jensen and Meckling, 1976) large shareholders are more motivated and have greater power to guarantee the maximization of shareholder value. Managerial ownership of company shares can align management interests with other shareholders interests so as to reduce the potential for agency conflict. Greater managerial ownership causes management to be more careful in using debt because they also bear the consequences of their actions so that management tends to use low debt. Higher the level of managerial ownership in the company will reduce the company's debt policy.

The results of the research conducted by Indana (2010), Natasia and Wahidahwati (2015) found that managerial ownership had a negatively significant effect on debt policy. Based on the description above, the following hypotheses can be formulated:

\section{H1: Managerial ownership has a negative effect on the company's debt policy}

\subsection{Effect of Institutional Ownership on Debt Policy}

Institutional ownership has better capabilitiesthan individual ownership. Large institutional ownership can affect the company's debt policy. It functions as a means of monitoring management activities. The higher the institutional ownership, the more effective monitoring of institutional investors will be on manager's actions. The existence of good monitoring affects the decline in the use of debt because the role of debt as a mechanism to reduce agency costs has been taken over by the ownership of the institution. Thus, the greater the institutional ownership, the smaller the company's debt policy decreases.

The results of the research conducted by Wahidahwati (2002), Yeniatie and Destriana (2010), Milanto (2012), found that institutional ownership has a significant effect on debt policy. Based on the description above, the following hypotheses can be formulated:

\section{H2: Institutional ownership has a negative effect on debt policy}




\subsection{Effects of Company Growth on Debt Policy}

Company growth is a change in total assets both an increase and a decrease in company assets in one period or one year. Companies with high growth increasingly need high funding. Based on the cracking order theory which states that there is a sequence of corporate funding decisions, the company that has high growth should reduce its debt policy because a company with high growth will describe the company as having sufficient sources of funds to finance its activities. Companies with high growth show strong internal capability of the company in acquiring and managing its resources. This means that a growing company is able to manage assets to obtain funding sources.

The higher the growth rate of the company, the smaller the debt taken by the company because the company will prefer internal funding sources compared to riskier debt policy making. The results of the study conducted by Stefen and Lina (2011), Hardiningsih and Oktaviani (2012) found that the companygrowth had a negatively significant effect on the company's debt policy. Based on the description above, the hypothesis can be derived as follows:

\section{H3: Company growth has a negative effect on the company's debt policy}

\subsection{Effect of Free Cash Flow on Debt Policy}

Free cash flow is the excess cash needed to fund all projects that have a positive net present value after dividing dividends (Jensen, 1986). Jensen (1986) stated that market pressure encourages managers to distribute free cash flow to shareholders in the form of dividends or they will face the risk of losing control of the company.

Companies that have high free cash flow tend to have high debt especially for companies that have low investment opportunities. High debt is intended to reduce the occurrence of agency sost that comes from free cash flow. This decrease reduces discreationary sources, especially cash flow, under management control. Based on this, there is a positive relationship between the free cash flow and the level of company debt.

The results of the research conducted byIndahningrum and Handayani (2009), Natasia and Wahidahwati (2015) found that free cash flow has a positively significant effect on debt policy. Thus, the hypothesis can be formulated as follows:

\section{H4: Free Cash Flow has a positive effect on debt policy}

\subsection{Effect of Company Size on Debt Policy}

Company size is a scale that can be classified in the size of the company in various ways, including total assets, stock market value, sales stability, number of employees and total debt. The size of the company reflects the high and low operating activities of the company. In general, the larger the company, the greater the activity (Hastalona, 2013). Large activities will require a large amount of funding needs for these activities. The main source of funding that is easier to obtain is from outside the company (external).

Companies with large sizes have the ability and broader access to obtain external sources of funding to obtain loans or debt. Weston and Copeland (1995) in Hastalona (2013) stated that large companies will be easier to enter the capital market, which means that there is flexibility and the company's ability to create debt. Based on this theory there is a positive relationship between company size and company debt policy. The larger the size of the company, the greater the company's debt policy.

The results of the research conducted by Milanto (2012) found that the size of the company had a significant positive effect on debt policy. From the description above, the hypothesis can be derived as follows:

\section{H5: Company size has a positive effect on debt policy}

\subsection{Effects of Debt Policy on Company Values}

The company's funding policy in the form of debt policy affects the value of the company. According to Fenandar and Raharja (2012) an increase in debt is interpreted by outsiders as the company's ability to pay its obligations in the future or a low business risk, this will be responded positively by the market. Positive responses from the market will increase the value of the company.

Brigham and Houston (2003) through a trade-off theory explained that the greater the proportion of corporate debt, the greater the tax protection that the company will get because debt provides benefits for tax protection. The increase in debt resulted in an increase in the company's operating profit, namely pre-tax profit (EBIT) flowing to investors that increase. Thus, greater the company's debt results in the higher the value of the company. 
Frank and Goyal (2003) in Sari and Wijayanto (2015) stated that large companies tend to add debt to support dividend payments. The higher the level of debt, the more funds available to pay dividends. This will give a positive signal to investors and cause the value of the company to rise.

The results of the study conducted by Sukrini (2012), Afzal and Rohman (2012), Hermuningsih (2013), Irvaniawati and Urtiyati (2014), Rofika (2017) found that the company's debt policy influences the value of the company.

Based on the aforementioned matters, the following hypotheses are derived:

\section{H6: Debt policy has a positive effect on company value}

\section{Research methods}

\subsection{Populations and Samples}

The population of this study was all manufacturing companies listed on the Indonesia Stock Exchange for the period of 2015-2017. While the research sample was selected based on the purposive sampling method with the following criteria:

1. Registered on the Indonesia Stock Exchange during the research period, from 2015 to 2017.

2. Having complete and accessible financial reports and annual reports during the research period, namely 2015 to 2017.

3. The financial statements expire on December 31.

4. Using the Rupiah as a reporting currency.

5. Having complete data needed for research.

Based on the above criteria, 91 sample companies are obtained.

\subsection{Data and Sources}

The data needed in this study are secondary data in the form of financial statements and company annual reports which become sample. Data needed in the form of managerial and institutional ownership and financial data related to this research. The data is obtained from the Indonesia Stock Exchange website www.idx.co.id.

\section{- Variable measurements}

Measurements for each of these variables are:

\section{- Debt policy.}

Debt policy is a company policy to finance its operations originating from debt. Debt policy shows how much the debt and equity ratio of the company is in financing its operations. Debt policy is measured using Debt to Equity Ratio (DER). The use of this ratio refers to previous research (Mayogi and Fidiana, 2016). The DER ratio is calculated as follows:

\section{- The company value.}

$$
D E R=\frac{\text { Total Debt }}{\text { TotalEquity }}
$$

Company value is a description of the condition of a company where there is a special assessment by prospective investors on company performance as reflected in the company's stock price. Company value is measured using Price to Book Value (PBV) Ratio. The use of this ratio refers to previous research (Mayogi and Fidiana, 2016). $\mathrm{PBV}$ ratio is calculated as follows:

$$
P B V=\frac{\text { Market price per share }}{\text { Book value per shares }}
$$

\section{- Managerial ownership.}

Managerial ownership is the percentage of shares held by company management compared to the total number of outstanding shares, which are calculated as follows:

$\mathrm{MGT}=\frac{\text { the number of shares owned by management }}{\text { Total outstanding shares }} \mathrm{X} 100 \%$

\section{- Institutional ownership.}

Institutional ownership is the percentage of shares owned by management of the company compared to the total number of outstanding shares, which are calculated as follows:

$$
\text { INST }=\frac{\text { Number of institutional shares }}{\text { Total outstanding shares }} \times 100 \%
$$

\section{- Company growth.}


Company growth is a change in total assets in one period or one year. The company growth is calculated as follows:

$$
\text { GROWTH }=\frac{\text { Year }- \text { end total assets }}{\text { Total assets at the beginning of the year }}
$$

\section{- Free Cash Flow.}

Free Cash Flow describes the amount of cash available at the company after the company meets its operational and investment needs. Free cash flow is calculated using the Ross' et. Al. (2000) formula as follows:

$$
\begin{aligned}
& \mathrm{FCF} \text { it }=\mathrm{AKO}_{\mathrm{it}}-\mathrm{PM}_{\mathrm{it}}-\mathrm{NWC}_{\mathrm{it}} \\
& \mathrm{FCF} \quad=\mathrm{i} \text { company's Free cash flow in year } \mathrm{t} \\
& \mathrm{AKO}=\mathrm{i} \text { company operating cash flow in year } \mathrm{t} \\
& \mathrm{PM} \quad=\mathrm{i} \text { company capital expenditurein year } \mathrm{t} \\
& \mathrm{NWC}=\mathrm{i} \text { company's net working capital in year } \mathrm{t}
\end{aligned}
$$

\section{- Company size.}

The company size in this study uses the total assets of the company in a period. Company size is measured using lognatural total assets in year $\mathrm{t}$.

Size $=$ Ln Total Aset ${ }_{t}$

\subsection{Hypothesis Testing}

This study examines the effect of independent variables on the dependent variable. The hypotheses proposed in this study would be analyzed using multiple linear regression equations that use the two equation models as follows: For testing hypotheses 1 to 5 :

$$
\mathrm{DER}=\alpha+\beta_{1} \mathrm{MGT}+\beta_{2} \mathrm{INST}+\beta_{3} \mathrm{CFC}+\beta_{4} \mathrm{GROWTH}+\mathrm{SIZE}+\varepsilon
$$

For testing hypothesis 6:

$$
\mathrm{PBV}=\alpha+\beta_{1} \mathrm{DER}+\varepsilon
$$

The hypotheses proposed would be tested using statistical $t$ test. The $t$ test was done by comparing the value of $t$ count and t table with a 95\% confidence level and a significance level $(\alpha)$ of $5 \%$. The acceptance criteria of the hypotheses were: if the value of $\mathrm{t}$ count $>\mathrm{t}$ table or the value of $-\mathrm{t}$ count $<-\mathrm{t}$ table or if the value of $\mathrm{P}$ value $<$ of $\alpha$, then the hypothesis would be accepted.

\section{Results and Discussion}

4.1 Descriptive Statistics Test Results

Descriptive Statistics Test Results which included the minimum, maximum and average values for each variable can be seen in the following table:

Table 2. Descriptive Statistics Test Results

Descriptive Statistics

\begin{tabular}{|l|r|r|r|r|}
\hline & $\mathrm{N}$ & \multicolumn{1}{|c|}{ Minimum } & \multicolumn{1}{c|}{ Maximum } & \multicolumn{1}{c|}{ Mean } \\
\hline DER & 273 & -1.202800 & 11.097900 & 1.12843773 \\
PBV & 273 & .001600 & 12.541200 & 2.13267799 \\
MGT & 273 & .000000 & 89.444400 & 4.80933407 \\
INST & 273 & .000000 & 99.429700 & 58.65649963 \\
GROWTH & 273 & -.861700 & 16.460200 & .20760696 \\
FCF & 273 & $-3.272900 \mathrm{E} 13$ & $1.004313 \mathrm{E} 13$ & $-1.48781609 \mathrm{E} 12$ \\
SIZE & 273 & 23.317000 & 33.320200 & 28.21687436 \\
Valid N (listwise) & 273 & & & \\
\hline
\end{tabular}




\subsection{Multiple Linear Regression AnalysisResults}

The proposed hypotheses were tested using multiple linear regression analysis. For H1 - H5 multiple linear regression analysis was used with this following equation:

$$
\mathrm{DER}=\alpha+\beta_{1} \mathrm{MGT}+\beta_{2} \mathrm{INST}+\beta_{3} \mathrm{FCF}+\beta_{4} \mathrm{GROWTH}+\mathrm{SIZE}+\varepsilon
$$

The results of multiple linear regression analysis for H1 - H5 is described in table 4.2 below:

Table 3. H1 - H5 Multiple Regression AnalysisResults

\begin{tabular}{|l|c|c|c|c|}
\hline \multicolumn{1}{|c|}{ Variable } & Coefficient & t-count & Significance & Conclusion \\
\hline Constanta & $-1,163$ & & & \\
\hline MGT & $-0,014$ & $-2,239$ & 0,026 & Takes Effect \\
\hline INST & $-0,001$ & $-0,411$ & 0,681 & No effects \\
\hline GROWTH & $-0,022$ & $-0,372$ & 0,710 & No effects \\
\hline FCF & $6,972 \mathrm{E}-14$ & 3,574 & 0,000 & Takes Effect \\
\hline SIZE & 0,090 & 1,683 & 0,094 & No effects \\
\hline $\mathrm{R}^{2}=0,064$ & Adj $\mathrm{R}^{2}=0,047$ & F-count $=3,668$ & F sig $=0,003$ \\
\hline
\end{tabular}

For testing H6 a simple regression equation was used with this following equation:

$$
\mathrm{PBV}=\alpha+\beta_{1} \mathrm{DER}+\varepsilon
$$

The simple regression analysis results for H6 is described as in Table 4.3 below:

Table 4. Simple Regression Analysis for H6 Results

\begin{tabular}{|c|c|c|c|c|}
\hline Variable & Coefficient & t-count & Significance & Conclusion \\
\hline Constanta & 2,004 & & & No effects \\
\hline DER & 0,114 & 1,00 & 0,318 & F sig $=0,318$ \\
\hline $\mathrm{R}=0,061$ & $\mathrm{R}^{2}=0,04$ & $\mathrm{~F}=1,000$ & \multicolumn{2}{c|}{} \\
\hline
\end{tabular}

\subsection{Discussion}

\subsubsection{Effects of Managerial Ownership on Debt Policy}

The first hypothesis (H1) of this study is: Managerial ownership has a negative effect on the company's debt policy. From the output results in table 4.5, the significance value (p-value) is 0.026 . This p-value is smaller than the significance value $(\alpha=5 \%)$. It can be concluded that hypothesis 1 is accepted, with a negative direction. This means that managerial ownership affects the debt policy in the opposite direction. The greater the managerial ownership, the smaller the company's debt policy.

The company's debt policy decision is the responsibility of the management as the company manager. Greater managerial ownership results in management that becomes more careful in using debt because they also bear the consequences of their actions. Failure to pay off debts will also be borne by management as the owner of the company, so management tends to use low debt in the company's operations.

The results of this study are in line with the research conducted byIndana (2010), Natasia and Wahidahwati (2015). Howeverthe results of this study are not in line with the research conducted by Nasrizal (2010), Oktaviani (2012), Larasati (2011), Indahningrum and Handayani (2009).

\subsubsection{Effect of Institutional Ownership on Debt Policy}

The second hypothesis (H2) of this study is: Institutional ownership negatively affects the company's debt policy. From the output results in table 4.5 , the significance value (p-value) is 0.681 . This $\mathrm{p}$-value value is greater than the significance value $(\alpha=5 \%)$. It can be concluded that $\mathrm{H} 2$ is not acceptable, with a negative direction. This means that managerial ownership does not affect the debt policy in the opposite direction. The greater the institutional ownership, the smaller the company's debt policy.

Institutional ownership is a mechanism for monitoring management behavior. The existence of good monitoring affects the decline in the use of debt because the role of debt as a mechanism to reduce agency costs has been taken over by the institutional ownership. In the theory, the greater the managerial ownership, the smaller the company's debt policy.

In this study institutional ownership has no effect on debt policy. The average institutional ownership sample was $58.656 \%$. This institutional ownership is not too large. The lack of influence of institutional ownership on debt 
policy in this research is probably caused by institutional ownership that is not too large(58.656\%). Thus, institutional ownership does not play an active role in monitoring management actions.

The results of this study are in line with the study conducted by Narita (2012), Surya and Rahayuningsih (2012) and Natasia and Wahidahwati (2002). This study did not succeed in supporting the research conducted by Yeniatie and Destriana (2010), Milanto (2012), who found that institutional ownership had a significant effect on debt policy.

\subsubsection{Effect of Company Growth on Debt Policy}

The third hypothesis (H3) of this study is: Company growth has a negative effect on the company's debt policy. From the output results in table 4.5, the significance value (p-value) is 0.710 . This $p$-value value is greater than the significance value $(\alpha=5 \%)$. It can be concluded that $\mathrm{H} 3$ is not acceptable, with a negative direction. This means that company growth has no effect on debt policy in the opposite direction. The bigger the company's growth, the smaller the company's debt policy.

Companies with high growth demonstrate the company's strong internal capabilities in acquiring and managing its resources. This means that a growing company is able to manage assets to obtain funding sources. The higher the growth rate of the company, the smaller the debt taken by the company because the company will prefer internal funding sources compared to riskier debt policy making.

In this study the growth of the company has no effect on debt policy. The average growth of the sample companies is $0.207(20.7 \%)$. The lack of influence of the company's growth on the company's debt policy is probably due to the small percentage of company growth $(20.7 \%)$. Or it could also be caused by more corporate funding originating from debt.

This research is in line with the research conducted by Indah ningrum and Handayani (2009) and Natasia and Wahidahwati (2015). The results of this study did not succeed in supporting the research conducted by Stefen and Lina (2011), Hardiningsih and Oktaviani (2012) who found that company growth had a negativelysignificant effect on corporate debt policy.

\subsubsection{Effect of Free Cash Flow on Debt Policy}

The fourth hypothesis (H4) of this study is: Free Cash Flow has a positive effect on corporate debt policy. From the output results in table 4.5 , the significance value (p-value) is 0,000 . This $p$-value is smaller than the significance value $(\alpha=5 \%)$. It can be concluded that $\mathrm{H} 4$ is accepted, with a positive direction. This means that free cash flow affects the debt policy in the same direction. The greater the free cash flow, the greater the company's debt policy.

Companies that have high free cash flow tend to have high debt especially for companies that have low investment opportunities. High debt is intended to reduce the occurrence of agency sost that comes from free cash flow. This decrease reduces discreationary sources, especially cash flow, under management control.

This study successfully supported the research conducted by Indahningrum and Handayani (2009), Natasia and Wahidahwati (2015) who found that free cash flow had a positivelysignificant effect on debt policy.

\subsubsection{Effect of Company Size on Debt Policy}

The fifth hypothesis (H5) of this study is: Company size has a positive effect on corporate debt policy. From the output results in table 4.5, the significance value ( $\mathrm{p}$-value) is 0.094 . This $\mathrm{p}$-value value is greater than the significance value $(\alpha=5 \%)$. It can be concluded that H5 is not acceptable, with a positive direction. This means that the size of the company does not affect debt policy in the same direction. The larger the companysize, the greater the company's debt policy.

In this study, the company size does not affect the company's debt policy. This is probably due to the fact that most sample companies of the research were not in the category of large companies, and the possibility of companies that are included to the category of small companies prefer to obtain funds originating fromthe issuance of equity compared to debt. This also relates to risk if it uses debt as a source of corporate funding.

The results of this study are in line with the research conducted by Soesetio (2008) and Sujarweni et al (2014) who found that company size did not affect debt policy. However, the results of this study contradicted the results of research by Milanto (2012). 


\subsubsection{Effect of Debt Policy on Company Values}

The sixth hypothesis (H6) of this study is: Debt policy has a positive effect on company value. From the output results in table 4.6 , there is a significance value ( $p$-value) of 0.318 . This $p$-value value is greater than the significance value $(\alpha=5 \%)$. It can be concluded that H6 is not acceptable, with a positive direction. This means that debt policy does not affect the companyvalue. The larger the company size, the greater the company's debt policy.

The company value is proxied to Price to Book Value (PBV). The company value will be reflectedin the market value of the company's stock. The market price is determined based on demand and supply. The non-influencing debt policy on the company value may be caused by investors that do not consider the importance of company's financial information in determining investment decisions. Generally, investors in the Indonesian capital market (BEI) pay more attention to other non-financial information in making investment decisions, for example new policies by companies or government. In addition, it is also possible for investors to assume that the debt made by the company will give a high risk to the company which will affect them. Thus, the debt policy does not affect the companyvalue.

The results of this study are in line with the research conducted by Mardiyati (2012), Martikarini (2012), Mayogi (2012) and Sari and Wijayanto (2015).

\section{Conclusions and Suggestions}

\subsection{Conclusion}

This study aims to examine the effect of managerial ownership, institutional ownership, company growth, free cash flow and company size on the company's debt policy. Furthermore, this study also examines the impact of debt policy on company value. Based on statistical testing on regression data analysis with the help of the SPSS program, using a degree of freedom of $95 \%$ and a significance level $(\alpha)$ of $5 \%$, the following conclusions were obtained:

1. Managerial policy influences the policies of manufacturing companies during 2014-2016 with negative direction. This means that greater managerial ownership will reduce the company's debt policy.

2. Institutional ownership does not affect the manufacturing company policy during 2014-2016 with a negative direction. This means that greater institutional ownership will reduce the company's debt policy.

3. The company growth does not affect the manufacturing company debt policy during 2014-2016 in a negative direction. This means that the higher the company's growth, the lower the company's debt policy.

4. Free Cash Flow affects the manufacturing company debt policy during 2014-2016 in a positive direction. This means that the greater the company's free cash flow, the greater the company's debt policy.

5. The company size does not affect the debt policy of manufacturing companies during 2014 - 2016 with a positive direction. This means that the larger the size of the company, the greater the company's debt policy.

6. Debt policy does not affect the value of manufacturing companies during 2014-2016 with a positive direction. This means that the greater the company's debt policy, the greater the value of the company.

\subsection{Suggestions}

This research still has weaknesses and shortcomings. Suggestions for future researchers based on the weaknesses of this study are:

1. Research was only done in one industrial sector, namely manufacturing, so it only represents the manufacturing sector. To obtain results and conclusions that represent all sectors, the future research should be conducted for each industrial sector in all industrial sectors on the IDX. So that variables can influence the company's debt policy for each industrial sector.

2. The adjusted $\mathrm{R}^{2}$ value of this study is only 0.047 . This means that only $4.7 \%$ of the research variables affect the company's debt policy. For future researchers can replace independent variables with other variables, both those that have been tested or have not been investigated by previous researchers.

3. Out of the five (5) independent variables examined for their influence on the company's debt policy only two (2) variables were influential. The absence of the influence of these independent variables is likely to be mediated by intervening variables. So that the future researcher can use intervening or mediating variables. 


\section{References}

Arie Afrizal dan Abdul Rohman. 2012. Pengaruh Keputusan Investasi, Keputusan Pendanaan, dan Kebijakan Dividen terhadap Nilai Perusahaan. Jurnal Akuntansi Diponegoro. Vol 1. No. 2. Hal: 1-9.

Brigham, E. F. dan M.C. Ehrhar dt. 2005. Financial Management : Theory and Practice. 11 the edition. United States : SouthWestern.

Brigham, Eugene F. And Joel F. Houston. 2003. Fundamentals of Financial Management. 9th Edition, Horcourt College, United States of America.

Desi Milanto. 2012. Analisis Faktor-faktor yang Mempengaruhi Kebijakan Hutang. Dinamika Manajemen. Vol 2 (3) hal: $97-$ 112.

Dina Hastalona. 2013. Analisis Faktor-faktor yang Mempengaruhi Kebijakan Hutang. Jurnal Keuangan dan Bisnis. Vol.5. No. 1. Maret 2013

Dwi.Sukrini. 2012. Kepemilikan Manajerial, Kepemilikan Institusional, Kebijakan Dividen dan Kebijakan Hutang: Analisis Terhadap Nilai Perusahaan. Accounting Analysis Journal. Vol 1. No. 2. Hal: 1-12.

Eva Larasati. 2011. Pengaruh Kepemilikan Manajerial, Kepemilikan Institusional dan Kebijakan Dividen terhadap Kebijakan Hutang Perusahaan. Jurnal Ekonomi Bisnis, Th 16, No.2, Juli 2011.

Evrila Lupita Sari dan Andhi Wijayanto. 2015. Pengaruh Keputusan Investasi, Pendanaan dan Dividen terhadap Nilai Perusahaan dengan Risiko Sebagai Variabel Mediasi. Management Anasysis Journal. Vol 4. No. 4 hal 281-291.

Gany Ibrahim Fennadar dan Surya Raharja. 2012. Pengaruh Keputusan Investasi, Keputusan Pendanaan, dan Kebijakan Dividen terhadap Nilai Perusahaan. Diponegoro Journal of Accounting. Vol 1. No. 2. Hal: 1-10.

Hardiningsih, P. Dan R. Oktaviani. 2012. Determinan Kebijakan Hutang (Dalam Agency Theory dan Pecking Order Theory). Dinamika Akuntnasi, Keuangan dan Perbankan. Vol 1. No. 1 (Mei) hal: 11-24.

Irvaniawati dan Sri Urtiyati. 2014. Analisis Pengaruh Kebijakan Hutang, Kebijakan Investasi, dan Kebijakan Dividen terhadap Nilai Perusahaan. Jurnal Ilmu \& Riset Manajemen. Vol. 3. No. 6 . Hal: 1-19.

Indana, R. 2010. Pengaruh Kepemilikan Manajerial, Kepemilikan Institusional, Dividen dan Struktur Aset terhadap Kebijakan Utang pada Perusahaan Manufaktur yang Masuk Daftar Efek Syariah. Skripsi. Program Studi Keuangan Islam Fakultas Syariah dan Hukum UIN Sunan Kalijaga. Yogyakarta.

Jensen, Michael C, and W.H. Meckling. 1976. Theory of the Firm: Managerial Behavior, Agency Cost and Ownership Structure. Journal of Financial Economics. p 305-360.

Keown, J. Arthur. Et al. 2011. Management Keuangan: Prinsip dan Penerapan. Edisi 10, Jilid pertama. Penerbit Indeks Jakarta. Latief lasari Hani Diana. 2011. Analisis Faktor-faktor yang Mempengaruhi Kebijakan Dividen. Skripsi. Fakultas Ekonomi Universitas Diponegoro.

Nasrizaldkk. 2010. Analisis Pengaruh Free Cash Flow, Kebijakan Dividen, Kepemilikan Saham Manajerial dan Kepemilikan Institusional terhadap Kebijakan Hutang. Jurnal Ekonomi. Vol 18 (4).

Nisa Fidyati. 2003. Faktor-faktor yang Mempengaruhi Kebijakan Utang Perusahaan. Jurnal Ekonomi, Manajemen dan Akuntansi. Vol 1, No.1, Januari, hal 17-34.

Rizka Putri Indahningrum dan Ratih Handayani, 2009. Pengaruh Kepemilikan Manajerial, Kepemilikan Institusional, Dividen, Pertumbuhan Perusahaan, Free Cash Flow dan Profitabilitas terhadap Kebijakan Hutang Perusahaan. Jurnal Bisnis dan Akuntansi. Vol 11 (3) hal: 189-207.

Rofika dan Zulbahridar. 2017. Pengaruh Kebijakan Perusahaan dan Profitabilitas terhadap Nilai Perusahaan. Laporan Penelitian Fakultas Ekonomi Universitas Riau.

Sri Hermuningsih. 2013. Pengaruh Profitabilitas, Growth Opportunity, Struktur Modal Terhadap Nilai Perusahaan Publik di Indonseia. Buletin EkonomiMoneter dan Perbankan. Oktober. Hal: 127 - 148.

Suad Husnan dan Enny Pudjiastuti. 20102. Dasar-dasar Management Keuangan. Edisikeenam, cetakan pertama. UPP STIM YKPN Yogyakarta.

Sujoko dan U. Soebiantoro. 2007. Pengaruh Struktur Kepemilikan Saham, Leverage, Faktor Intern dan Faktor Ekstern terhadap Nilai Perusahaan. Jurnal Manajemen dan Kewirausahaan. Vol.9. No. 1. Maret: hal 41 - 48.

Surya, D dan D.A. Rahayuningsih. 2012. Faktor-faktor yang Mempengaruhi Kebijakan Hutang Perusahaan Non Keuangan yang Terdaftar di Bursa Efek Indonesia. Jurnal Bisnis dan Akuntansi. Vol 14 (3) hal: 213-225. 
V. Wiratna Sujarweni, Marsudi Endang dan Lila Retnani. 2014. Faktor-faktor yang Mempengaruhi Kebijakan Hutang (studi Empiris pada Perusahaan Manufaktur yang Terdaftar di BEI tahun 2009-2012). Jurnal Bisnis Teori dan Implemetasi. Vol V. No.1. Februari 2014. hal: 42-56.

Wahidahwati. 2002. Pengaruh Kepemilikan Majaerial dan KepemilikanInstitusional pada Kebihajakan Hutang Perusahaan: Sebuah Perspektif Theory Agency. Jurnal Riset Akuntansi Indonesia. Vol 5. No.1.

Weka Natasia dan Whidahwati. 2015. Faktor-faktor yang Mempengaruhi Kebijakan Hutang Perusahaan yang Terdaftar di BEI. Jurnal Ilmu \& Riset Akuntansi. Vol 4. No. 12 hal: 1-22.

Yaniatie dan N. Destriana. 2010. Faktor-faktor yang Mempengaruhi Kebijakan Hutang pada Perusahaan Non Keuangan yang Terdaftar di Bursa Efek Indonesia. Jurnal Bisnis dan Akuntansi. Vol 12 (1) hal: 1-16.

https://investasi.kontan.co.id/news. diakses pada 29 Mei 2018.

https://emitennews.com/diakses pada 29 Mei 2018. 